\title{
Jaminan Pemeliharaan Kesehatan Masyarakat ( JPKM)
}

\author{
Herlina Eka Shinta
}

\begin{abstract}
ABSTRAK
Jaminan pemeliharaan kesehatan masyarakat (JPKM) merupakan satu strategi yang mendekatkan akses masyarakat terhadap pelayanan kesehatan karena sistemnya managed care, pelayanan yang komprehensif dengan mengutamakan pencegahan dan peningkatan tanpa melupakan pengobatan dan pemulihan, mengurangi bahaya moral dari semua pelaku JPKM, sesuai dengan budaya gotong royong masyarakat. Keuntungan bagi seluruh pelaku JPKM dengan syarat terjadi hubungan harmonis diantara pelaku JPKM.
\end{abstract}

Kata kunci : JPKM, managed care

\section{PENDAHULUAN}

Indeks Pembangunan Manusia (IPM) Indonesia berada pada peringkat 103 dari 191 negara (WHO, 2000; UNDP, 2004) IPM ditentukan oleh tiga indikator yaitu pertama, indikator kesehatan yang diukur dari umur harapan hidup (UHH), angka kesakitan serta angka kematian ibu (AKI), kematian bayi dan anak bawah lima tahun (AKB), kedua, indikator pendidikan yang diukur dari angka melek huruf dan tingkat pendidikan serta ketiga adalah indikator ekonomi yang diukur dari pendapatan perkapita.

Walaupun telah terjadi penurunan AKI dan AKB serta peningkatan UHH namun Indonesia masih jauh tertinggal bila dibandingkan dengan beberapa negara Asia lainnya. Tingkat kesehatan masyarakat diperburuk oleh adanya krisis multidimensi; khusus dalam bidang kesehatan antara lain terjadi transisi epidemiologis yang menyebabkan Indonesia mengalami - beban ganda penyakit\| atau double burden of diseases, yaitu saat masalah penyakit infeksi belum hilang, sudah muncul masalah penyakit degeneratif misalnya penyakit jantung yang memerlukan biaya besar sementara dipiihak lain, pembiayaan kesehatan masih tetap merupakan masalah yang belum terselesaikan.

Ada dua masalah pembiayaan kesehatan di Indonesia yang merupakan isyu penting pada saat ini dan sangat dirasakan akibatnya oleh masyarakat yaitu disatu pihak biaya kesehatan semakin mahal, pada pihak lain subsidi pemerintah untuk biaya kesehatan sangat kecil yaitu hanya mencapai 2-3\%. Anggaran Pendapatan dan Belanja Negara (APBN) dan menurut WHO (2000) merupakan salah satu Negara dengan anggaran kesehatan terkecil yaitu kurang dari 2\% Gross Domestic Bruto (GDB) selain Somalia. Dengan demikian sebagian besar biaya kesehatan (70 \%) ditanggung oleh masyarakat dan dari biaya tersebut $85 \%$ dibayar secara langsung oleh masyarakat dari kantong sendiri dan hanya sebagian kecil (sekitar $15 \%$ ) saja dibayar melalui asuransi. Akibatnya masyarakat harus menyediakan dana tunai apabila mereka memerlukan pemeliharaan kesehatan dan bagi yang tidak mampu menyediakan dana tunai, mereka tidak akan akses atau mendapatkan pelayanan kesehatan. Dampaknya adalah derajat kesehatan masyarakat semakin buruk, Sumber Daya Manusia yang dihasilkan sangat lemah, padahal keberhasilan pembangunan suatu Negara sangat ditentukan oleh Sumber Daya Manusia (SDM) yang merupakan asset atau modal pembangunan. Sumber daya alam yang melimpah tidak akan berarti apa-apa tanpa SDM yang sehat, handal, mandiri dan mampu bersaing di era global.

Dinegara maju khususnya Jerman, Inggris, Belanda, Kanada, Amerika dan beberapa negara di Asia misalnya Jepang, pembiayaan melalui 
asuransi merupakan jalan keluar dari masalah pembiayaan kesehatan yang ada. Dibanding dengan negara maju lainnya, asuransi kesehatan di Amerika Serikat boleh dikatakan kurang berhasil karena hanya mencakup 70\% penduduk. Hal ini terjadi karena asuransi kesehatan yang dilaksanakan besrsifat komersial dan membuka peluang persaingan di antara berbagai perusahaan asuransi yang jumlahnya banyak. Sehingga partisipasi masyarakat terpecah- pecah. Akibatnya hukum jumlah besar tidak terpenuhi.

perorangan dirubah menjadi risiko kelompok dengan cara membayar sejumlah uang yang disebut premi kepada suatu badan penyelenggara (Bapel) sebagai pengganti biaya yang mungkin harus dikeluarkan untuk pelayanan kesehatan pada saat sakit. Agar risiko dapat disebarkan secara merata dan luas maka jumlah peserta harus cukup banyak ( hukum jumlah besar ). Pembiayaan kesehatan melalui asuransi memberikan beberapa keuntungan, antara lain (1) meningkatkan pelayanan kesehatan bagi masyarakat, (2) membebaskan peserta dari kesulitan menyediakan uang tunai setiap kali berobat, (3) memungkinkan dapat diawasinya biaya dan mutu pelayanan kesehatan serta (4) menyediakan data kesehatan yang diperlukan.

Peluang untuk menjalankan pembiayaan kesehatan melalui asuransi di Indonesia sebetulnya cukup besar karena jumlah penduduk yang besar serta undang-undang Jaminan Kesehatan Nasional yang sedang dalam proses. Hanya, diperlukan komitmen dari semua pihak khususnya pemerintah baik pusat maupun daerah dalam pelaksanaannya serta perlu diwaspadai beberapa kendala misalnya semakin banyaknya perusahaan asuransi asing yang bergerak di Indonesia. Keadaan ini, diperburuk dengan kebiasaan yang lebih memilih produk asing daripada produk nasional, walaupun dapat dimaklumi karena saat ini sedang terjadi krisis kepercayaan terhadap pemerintah kita.

Untuk itu diperlukan sistem asuransi yang sesuai dengan keadaan masyarakat Indonesia namun tetap mampu menjaga mutu sekaligus mengendalikan biaya pelayanan kesehatan. Model asuransi yang memenuhi kriteria tersebut dinamakan manage care, salah satu contohnya adalah Jaminan Pemeliharaan Kesehatan Masyarakat (JPKM).

\section{JENIS-JENIS ASURANSI}

Ditinjau dari berbagai pendekatan, asuransi terbagi dalam berbagai jenis, antara lain berdasarkan keikutsertaan anggota, asuransi terbagi menjadi asuransi kesehatan wajib dan sukarela, sedangkan jika ditinjau dari jumlah peserta yang ditanggung, terbagi menjadi asuransi kesehatan perorangandan asuransi kesehatan kelompok, selain itu berdasarkan sifatnya terbagi menjadi asuransi kesehatan sosial dan asuransi kesehatan komersial.Pendapat masyarakat yang selama ini menganggap — gratis\| terhadap sesuatu yang berbau — sosiall harus dihilangkan. Manusia sebagai mahluk sosial mempunyai arti yang lebih mendalam, bukan - sangat tergantung terhadap orang lain\| tetapi — saling bergantung satu sama lain\| sehingga terjadi suatu hubungan antar manusia yang harmonis seperti makna dari hablumminannas. Sejalan dengan itu, yang dimaksud dengan asuransi kesehatan sosial adalah asuransi yang sifatnya wajib bagi seluruh penduduk, premi dibayar berdasarkan persentase pendapatan, seluruh peserta mendapatkan paket pelayanan kesehatan yang sama dan bagi masyarakat tidak mampu, premi dibayar oleh negara. Dengan asuransi sosial, terjadi subsidi silang yaitu yang sehat menyumbang yang sakit, yang kaya menyumbang yang miskin, yang muda menyumbang yang tua, keluarga kecil menyumbang keluarga besar. Di Jerman prinsip ini dikenal dengan nama prinsip solidaritas. 


\section{PERKEMBANGAN ASURANSI KESEHATAN DI INDONESIA}

Sebetulnya asuransi kesehatan bukan barang baru di Indonesia. Asuransi kesehatan dibentuk pertamakali berdasarkan Surat Keputusan Presiden RI No.230 tahun 1968 yang dimulai dari Pegawai Negeri Sipil (PNS) dan penerima pensiun. Kemudian dikeluarkan tiga buah undang-undang yang berkaitan dengan asuransi kesehatan, yaitu pertama, Undang-undang No.2 Tahun 1992 dan Pear turan Pemerintah (PP) No.69 Tahun 192 yang melandasi PT ASKES untuk memperluas kepesertaannya diluar PNS dan penerima pensiun yang disebut Asuransi Kesehatan Sukarela. Kedua Undang-undang No.3 Tahun 1992 tentang Jaminan Sosial Tenaga Kerja (JAMSOSTEK) dan ketiga, Undang-undang Kesehatan No.23 Tahun 1992 pasal 1 dan pasal 66 tentang JPKM.

Demikian besar harapan terhadap manfaat asuransi dalam penanggulangan masalah pembiayaan kesehatan di Indonesia, dapat dilihat dari pencanangan JPKM menjadi salah satu strategi pencapaian Indonesia sehat 2010. Selain itu, saat ini pemerintah sedang mempersiapkan undang- undang untuk suatu model pembiayaan kesehatan yang akan diberlakukan secara Nasional dan sifatnya wajib yang dinamakan Jaminan Kesehatan Nasional (JKN). Dalam rangka mendidik kemandirian dan agar masyarakat mampu bertanggung jawab terhadap diri sendiri maupun keluarganya, maka image pelayanan kesehatan gratis khususnya bagi masyarakat miskin sebaiknya dihilangkan. Masyarakat yang tidak mampu tetap harus dikenai kewajiban membayar premi, hanya preminya dibayar oleh Negara. Dibeberapa tempat misalnya di Balikpapan, Palembang dan Jogya, dana subsidi Bahan Bakar Minyak bagi masyarakat miskin telah dicoba dikelola dengan memakai prinsip-prinsip asuransi dan ternyata hasilnya sangat menggembirakan. Untuk melaksanakan hal tersebut pekerjaan yang terberat adalah pemutihan data penduduk, khususnya penduduk miskin karena program hanya akan berhasil apabila didasarkan pada data yang akurat.

\section{PILIHAN JPKM}

Untuk lebih memahami mengapa managed care yang salah satu contohnya JPKM dikatakan lebih tepat dibanding asuransi lainnya, kita perlu mengetahui cara-cara pembiayaan kesehatan sebelumnya, antara lain:

1. Cara pembiayaan dimulai dengan cara yang paling konvensional yaitu masyarakat memperoleh pelayanan kesehatan dengan membayar Penyelenggara Pelayanan Kesehatan (PPK) secara tunai dari koceknya langsung. Terjadi transaksi langsung antara dokter-pasien, pembayaran jasa dokter dilakukan secara langsung setelah tindakan yang lebih berorientasi kuratif. Tindakan sangat ditentukan oleh provider (pemberi pelayanan), akibatnya biaya cenderung naik dan tidak terjangkau oleh masyarakat.

2. Sistem asuransi ganti rugi, dalam sistem ini hubungan dokter-pasien masih terjadi secara langsung namun pasien akan mendapatkan penggantian dari Badan Penyelenggara (Bapel) untuk pembiayaan kesehatan yang dikeluarkannya.

3. Sistem asuransi dengan tagihan provider , dengan sistem ini terjadi hubungan dokter-pasien dengan pembayaran jasa dokter oleh pihak ketiga yaitu bapel asuransi.

4. Managed care adalah suatu bentuk asuransi kesehatan yang disusun berdasarkan jumlah anggota terdaftar (kapitasi) dengan kontrol mulai dari perencanaan pelayanan serta meliputi ketentuan : ada kontrak dengan PPK untuk pelayanan yang komprehensif, penekanan agar peserta tetap sehat sehingga utilisasi berkurang, unit layanan harus memenuhi standar yang telah ditetapkan serta ada program peningkatan mutu pelayanan. Pembayaran 
jasa provider dilakukan dengan cara pembayaran dimuka (pre-payment) atau setelah pelayanan diberikan namun PPK tetap dapat mempertanggung-jawabkan baik biaya maupun kualitas layanan.

JPKM merupakan salah satu bentuk managed care yang diterapkan di Indonesia saat ini. Ada empat pelaku JPKM, yaitu peserta, bapel, PPK dan Badan Pembina (Bapim). Pemerintah selaku Badan Pembina berperan sebagai regulator, dan berkewajiban membayar premi bagi masyarakat yang tidak mampu sesuai dengan Undang-Undang Dasar 45 bahwa masyarakat miskin dibiayai negara. Sedangkan bagi Pegawai Negeri Sipil (PNS), pemerintah berkewajiban mensubsidi PNS karena merupakan pemilik.

\section{JPKM SUATU STRATEGI}

Kecenderungan dimasa depan, yang mana pembiayaan kesehatan semakin meningkat, JPKM merupakan salah satu pilihan karena saling menguntungkan bagi semua pelaku JPKM. Adanya perubahan kebijakan pembiayaan kesehatan yang tercantum dalam Sistem Kesehatan Nasional 2004 dan Undang-Undang Jaminan Sosial Nasional yang sedang dalam proses, akan mengokohkan keberadaan JPKM sebagai salah satu embrio pembiayaan kesehatan. Walaupun mungkin nantinya akan ada perubahan nama atau berbagai aturan main, namun JPKM telah terbukti mendekatkan akses masyarakat terhadap pelayanan kesehatan. Strategi ini akan berhasil apabila dilaksanakan dengan sistem asuransi kelompok karena akan memudahkan peningkatan jumlah kepesertaan sehingga sesuai dengan hukum jumlah besar serta adanya komitmen dan tanggung jawab serta hubungan harmonis seluruh pelaku Jaminan Pemeliharaan Kesehatan Masyarakat .

\section{Daftar Pustaka}

Azwar Azrul. 1996. Pengantar Administrasi Kesehatan, Edisi Ketiga, Jakarta : Binarupa Aksara.

Basa. R. 2002. Social Health Insurance System in Phillipine. Executive meeting on Development of Social Health Insurance in Indonesia. Jakarta.

Departemen Kesehatan dan Kesejahteraan Sosial RI. 2001. Profil Perkembangan Jaminan Pemeliharaan Kesehatan Masyarakat Tahun 2000. Jakarta : Direktorat Jaminan Pemeliharaan Kesehatan Masyarakat, Direktorat Jenderal Kesehatan Masyarakat. Departemen Kesehatan dan Kesejahteraan Sosial RI.

Departemen Kesehatan RI. 2000. JPKM : Pembinaan, Pengembangan dan Pendorongan JPKM. Jakarta.

HIAA Health Insurance Association of America, Part A. 1997. Fundamental of Health Insurance, Washington: The association.

Murti Bhisma. 2000. Dasar-dasar Asuransi Kesehatan, Jakarta: Kanisius.

Pongpingsut Yongudomsuk. 2002 . Thailand Health Insurance System; Executive meeting on Development of Social Health Insurance in Indonesia. Jakarta.

Stierle F. 2002. Social Health Insurance, Concept - Advantages - Prerequisites.

Executive meeting on Development of Social Health Insurance in Indonesia. 
Jakarta.

Sulastomo. 2002. Asuransi Kesehatan Sosial : Sebuah Pilihan. Jakarta: PT RajaGrafindo Persada. 9.

Thabrany Hasbullah. 2003. Social Health Insurance Implementation in Indonesia. Executive meeting on Development of Social Health Insurance in Indonesia. Jakarta.

Thabrany Hasbullah. 2005. Pendanaan Kesehatan dan Alternatif Mobilisasi Dana Kesehatan di Indonesia. Ed. 1. Jakarta: RajaGrafindo Persada.

UNDP. 2004. Human Development Report. (Online) http:// www.hdr.Undp.org/ Statistic/data/ Chy/Chy-f-idn.html.

World Health Organization. 2000. The World Health Report. Health Systems : Improving Performance. Geneva: WHO.

World Health Organization. 2005. Health Situation in the South-east Asia region, 1998-2000. (online) Available from http://w3.whosea.org/ health_situt_9800/c4n14.htm: 4 (accessed 30 August 2005). 